Georgetown University Law Center

Scholarship @ GEORGETOWN LAW

2013

\title{
Guiding Section 5: Comments on the Commissioners
}

Steven C. Salop

Georgetown University Law Center, salop@law.georgetown.edu

This paper can be downloaded free of charge from:

https://scholarship.law.georgetown.edu/facpub/1275

http://ssrn.com/abstract=2329730

This open-access article is brought to you by the Georgetown Law Library. Posted with permission of the author. Follow this and additional works at: https://scholarship.law.georgetown.edu/facpub

Part of the Antitrust and Trade Regulation Commons, and the Law and Economics Commons 


\title{
Guiding Section 5: Comments on the Commissioners \\ Steven C. Salop ${ }^{1}$
}

\begin{abstract}
This short note comments on the role of Section 5 distinct from the Sherman Act. It suggests that Section 5 be used to attack and deter certain conduct that falls into gaps of the Sherman Act. This includes exclusionary unilateral conduct that likely leads to the achievement, enhancement, or maintenance of market power (as opposed to monopoly power). It also includes unilateral conduct such as invitations to collude and other practices that facilitate conscious parallelism, tacit or express collusion, but are not uniquely or sufficiently "unequivocal" or "consequential" to violate Section 2 . The comment also explains why a limitation of Section 5 only to conduct with zero cognizable efficiency benefits would neutralize Section 5 and lead to under-deterrence problems and why a disproportionate harm standard also is problematical.
\end{abstract}

\section{INTRODUCTION}

FTC Commissioners Joshua Wright and Maureen Ohlhausen have proposed that the Commission adopt Guidelines for the application of Section 5 to Unfair Methods of Competition ("UMC"). ${ }^{2}$ These UMC Guidelines would apply to non-merger conduct that may not violate the Sherman Act. Agency Guidelines can provide a useful role in defining the scope of agency enforcement intentions and providing guidance to the business community, outside counsel, and agency staff. ${ }^{3}$ They also can lead to more refined legal standards. This short note will comment on the role of Section 5 distinct from the Sherman Act and how this relates to the Commissioners' proposed Guidelines.

\section{SECTION 5 AND SHERMAN ACT DISTINCTIONS}

A legal standard for Section 5 that is distinct from Sherman Act standards can play an important role in the overall system of antitrust enforcement. There are a number of gaps in the Sherman Act that permit harmful anticompetitive conduct and reduce deterrence. Consistent with the legislative mandate

\footnotetext{
${ }^{1}$ Professor of Economics and Law, Georgetown University Law Center; Senior Consultant, Charles River Associates. This note is based on my presentation at the ABA Post-Annual Meeting (August 15, 2013). I have benefited from our panel discussion and helpful comments from Jonathan Baker, Julie Brill, Jonathan Jacobson, and Joshua Wright. All opinions and errors remain my own. A version of this paper was prepared for the CPI Symposium on Section 5.

${ }^{2}$ Statement of Commissioner Joshua D. Wright, Proposed Policy Statement Regarding Unfair Methods of Competition Under Section 5 of the Federal Trade Commission Act (June 19, 2013) (hereinafter, Wright Statement), available at http://www.ftc.gov/speeches/wright/130619umcpolicystatement.pdf. Remarks of Commissioner Joshua D. Wright, Section 5 Recast: Defining the Federal Trade Commission's Unfair Methods of Competition Authority (June 19, 2013) (hereinafter, Wright Speech); Remarks of Commissioner Maureen K. Ohlhausen, Section 5: Principles of Navigation (July 25, 2013) (hereinafter, Ohlhausen Speech), available at http://www.ftc.gov/speeches/ohlhausen/130725section5speech.pdf.

${ }^{3}$ For criticisms of the use of Section 5, see William E. Kovacic \& Mark Winerman, Competition Policy and the Application of Section 5 of the Federal Trade Commission Act, 76 ANTITRUST L.J. 929 (2010).
} 
of the FTC to supplement the Sherman Act and Clayton Act, these gaps can be addressed with a Section 5 standard. $^{4}$

For example, neither Section 1 nor Section 2 of the Sherman Act reaches unilateral conduct that allows a firm or group of firms to achieve, maintain, or enhance market power, and facilitate its exercise. The market power might be exercised directly by a single firm or it might involve parallel accommodating conduct or other forms of tacit coordination that do not by themselves satisfy the Section 1 agreement requirement. As result, such conduct can lead to consumer harm of the type encompassed by the antitrust laws, yet not be prohibited or deterred by the Sherman Act. Applying Section 5 to conduct that causes harm to competition in this way can help to fill this gap. ${ }^{5}$

The need for this gap-filling is consistent with the insights of modern industrial organization economics:

- Most importantly, modern competitive effects analysis focuses on the likelihood and magnitude of the alleged price and output effects that are caused by the conduct, rather than the pre-existing degree of market power (or monopoly power). ${ }^{6}$ In fact, one can characterize both market power and monopoly power as the power to engage in conduct that leads to higher prices. ${ }^{7}$ Pre-existing power is only an imperfect proxy for the likelihood of harmful effects from allegedly anticompetitive conduct. Nor does the existence of market or monopoly power compel a finding of anticompetitive effects.

- Market power and monopoly power are essentially synonyms in economics, rather than having a bright line between them. ${ }^{8}$

- Market share often is a poor proxy for a firm's degree of monopoly or market power, so requiring a showing of a very high market share to find monopoly power leads to error.

- In a market in which firms interact repeatedly over time, market outcomes may not depend closely on where the conduct lies on the continuum between explicit collusion and purely parallel conduct.

${ }^{4}$ For the view that Section 5 standards should be the same as the Sherman Act, see A. Douglas Melamed, Comments: Workshop Concerning Section 5 of the Federal Trade Commission Act (October 14, 2008), available at http://ftc.gov/os/comments/section5workshop/537633-00004.pdf,

${ }^{5}$ Herbert J. Hovenkamp, The Federal Trade Commission and the Sherman Act, 62 FLORIDA L.R. 871 (2010) also suggests applying Section 5 in this way. Professor Hovenkamp also considers applying Section 5 to conduct analogous to "abuse of dominance." My comments here do not address the application of an abuse of dominance standard, which involves some further analysis.

${ }^{6}$ Thomas G. Krattenmaker \& Steven C. Salop, Anticompetitive Exclusion: Raising Rivals' Costs to Achieve Power Over Price, 96 YALE L.J. 209 (1986).

${ }^{7}$ Steven C. Salop, The First Principles Approach to Antitrust, Kodak, and Antitrust at the Millenium, 68 ANTITRUST L.J. 187 (2000). For example, opportunistically breaking a promise to an SSO that royalties will be FRAND (or deceiving the SSO or potential licensees that such a promise has been made) is conduct that can permit a patent holder to achieve market power after the licensees are locked-in and permit it to raise its royalty, thereby harming consumers as the royalty is passed on.

${ }^{8}$ It makes more economic sense for courts to treat monopoly power simply as a higher degree of market power. For example, see Thomas G. Krattenmaker, Robert H. Lande, \& Steven C. Salop, Monopoly Power and Market Power in Antitrust Law, 76 GEORGETOWN L.J. 241 (1987). 
However, courts often do not take these insights to heart. They erroneously act as if that there is an economic bright line between "market power" and "monopoly power," they sometimes make preexisting monopoly power a preliminary screen, and they generally require a very high market share for a finding of monopoly power. ${ }^{9}$ They also erroneously act as if there is an economic bright line between "agreements" and "conscious parallelism," and they have set a high bar for finding an agreement.

As a result, neither Section 1 nor Section 2 is sufficient to prohibit or deter a range of conduct that leads to consumer harm from the achievement and exercise of market power. A "screen" that relies on a showing of "monopoly power" or the existence of an "agreement" may eliminate false positives, but only at the cost of false negatives and under-deterrence.

Conduct that can lead to the achievement, enhancement, or maintenance of market power can include unilateral adoption of exclusive dealing, conditional price discounts (i.e., loyalty discounts and bundled discounts), most-favored nations terms, vertical restraints, breach of contract, and deception. Where this conduct involves vertical contracts (or other agreements) with suppliers or customers, it can be reached under Section 1. However, where the conduct is found to be unilateral, a gap may result. The unreached conduct also can include invitations to collude that are not uniquely or sufficiently "unequivocal" or "consequential" to violate Section $2 .{ }^{10}$

Section 5 is well-situated to fulfill the role of reaching this type of conduct as part of a rationally designed antitrust enforcement system. In principle, these competitive concerns could be incorporated into the Sherman Act. But, courts might be concerned that doing so would lead to over-deterrence because of the treble damages remedy that applies to most Sherman Act allegations. ${ }^{11}$ This same treble damages sanction also applies whether the defendant violates the Sherman Act by a little or by a lot. ${ }^{12}$ In contrast, a violation of Section 5 is not subject to treble damages. This weaker sanction may be appropriate for conduct that generally would be presumed to have somewhat less harmful effects on consumers, where it might be feared that treble damages would lead to over-deterrence. ${ }^{13}$

\section{AN APPROPRIATE GAP-FILLING STANDARD FOR SECTION 5}

This analysis suggests a Section 5 standard that shares some similarities with the approaches of Commissioners Wright and Ohlhausen, but with some other significant differences. Our major agreement is that the basic standard should be geared to the condemnation of unilateral conduct that

\footnotetext{
${ }^{9}$ They also sometimes fall victim to the "Cellophane Fallacy" and fail to recognize the existence of monopoly power.

${ }^{10}$ United States v. American Airlines, Inc., 743 F.2d 1114, 1119 (5th Cir. 1984).

${ }^{11}$ For example, see Copperweld Corp. v. Independence Tube Corp. 467 U.S. 752 (1984)

${ }^{12}$ This is not to say that there is never any tailoring of sanctions. Price-fixing is subject to criminal penalties, damages can differ according to the degree of conduct undertaken, and there can be punitive damages. In Section 2, more egregious exclusionary conduct might lead to a break-up remedy instead of conduct relief. Section 5 complaints sometimes lead to follow-on private actions under the Sherman Act or state laws that lead to exposure for treble damages. However, it is clear that violations of Section 5 involve lower expected sanctions. And, even in follow-on cases, the plaintiffs would not benefit from collateral estoppel in most cases.

${ }^{13}$ For example, traffic laws are tailored to the continuum of conduct concerns and likely effects. There is a higher sanction for more excessive speed, speeding in construction zones, or where the driver is impaired from alcohol or drugs. The permissible speed limit depends on the type of road and other conditions.
} 
allows a firm or firms to achieve, maintain, or enhance market power to the detriment of consumers, even if it does not lead to monopoly. ${ }^{14}$

Where we differ is the weight given to cognizable efficiencies. For example, Commissioner Wright proposes a two-pronged standard. His first prong requires a showing that the conduct would cause harm to consumers. Commissioner Wright refers to this as a "harm to competition" standard. His second prong requires a showing that there are "no cognizable efficiency benefits" flowing from the conduct. Both prongs must be satisfied for a violation of Section $5 .{ }^{15}$

Commissioner Ohlhausen adopts a similar first prong. However, she suggests a somewhat weaker second prong, that the "gross" consumer harms (i.e., ignoring efficiency consumer benefits) are "disproportionate" to the cognizable efficiency benefits, so that the "net" consumer harms are large. ${ }^{16}$ Commissioner Ohlhausen's proposed Guidelines also include a number of other conditions that must be satisfied. ${ }^{17}$

In contrast, I suggest a Section 5 standard analogous to the Section 1 rule of reason, but applied to unilateral conduct. Unilateral conduct would violate Section 5 if it leads to the achievement, maintenance, or enhancement of market power that likely harms consumers on balance, even after the consumer benefits from cognizable efficiencies of the conduct are taken into account. Thus, in order to justify the conduct, the cognizable efficiencies must be sufficiently large and sufficiently passed on to consumers to prevent that consumer harm. ${ }^{18}$

It is clear that this rule of reason can be applied to unilateral conduct as well as agreements. For example, the DC Circuit applied the basic Section 1 rule of reason to Section 2 in Microsoft and explained the benefits of doing so. ${ }^{19}$ My suggested standard is similar, but applied to the harms from achieving, maintaining, or enhancing market power instead of monopoly power. ${ }^{20}$

Thus, we all three have the same overarching goal of condemning conduct that harms consumers. ${ }^{21}$ However, I disagree with the Commissioners' approaches to the second prong, which over-

${ }^{14}$ Wright Statement at 8, supra note 2. Ohlhausen Speech at 7, supra note 2. As noted earlier, Section 5 also might be applied to conduct analogous to "abuse of dominance. See Hovenkamp, supra note 5. While I do not analyze Professor Hovenkamp's proposal here, I elsewhere have analyzed refusals to deal under the Sherman Act, and that analysis could be applied to Section 5 as well. Steven C. Salop, Refusals to Deal and Price Squeezes by an Unregulated, Vertically Integrated Monopolist, 76 ANTITRUST L.J. 709 (2010).

${ }^{15}$ Wright Statement at 9, supra note 2.

${ }^{16}$ Ohlhausen Speech at 7-8, 10, supra note 2. By "gross" harm to consumers, I mean the consumer harm that would occur if there were no consumer benefits from cognizable efficiencies. By "net" consumer harm, I mean the consumer harm suffered after the cognizable benefits passed on to consumers are taken into account.

${ }^{17}$ Ohlhausen Speech at 11-13, supra note 2.

${ }^{18}$ This is a "net" consumer harm standard. This approach is appropriate because the goal of antitrust laws is consumer welfare, not efficiency.

19 United States v. Microsoft Corporation 253 F.3d 34, 58-59 (2001).

20 My suggested approach would not require the Commission to make a mutually exclusive choice between pleading its complaint in terms of market power versus monopoly power, or between unilateral versus concerted conduct. The Section 5 standard would be like a lesser offense than the usual Sherman Act standard.

21 Note also that showing merely harm to competitors (and not consumer harm) is insufficient by itself to find a violation in all our approaches. Wright Statement at 5, supra note 2; Ohlhausen Speech at 7, supra note 2. In 
weight efficiencies and therefore can lead to outcomes that end up harming consumers. Our disagreements over this second prong are not new to antitrust policy debates. The very same standards and arguments have been raised with respect to Section 2 enforcement. ${ }^{22}$

The problems raised by the Commissioners' approaches are well illustrated by Commissioner Wright's proposal that conduct be immunized from attack under Section 5's UMC standard if it involves any cognizable efficiency benefits. Commissioner Wright has proposed his efficiency safe harbor to provide business certainty and prevent false positives, arbitrary enforcement, and over-deterrence. ${ }^{23}$ However, the safe harbor is not necessary to achieve these effects. The analysis of consumer harm under the rule of reason already entails analysis of cognizable efficiencies. The rule of reason also balances business certainty with concerns about false negatives and over-deterrence. ${ }^{24}$

Commissioner Wright apparently is most concerned with over-deterrence from the FTC's administrative process, where the FTC acts as prosecutor and judge and is not subject to the constraints from an independent court deciding motions to dismiss and summary judgment. ${ }^{25}$ However, there also are forces tipping in the other direction. First, the FTC is an expert body with significant economics resources available, resources that presumably can be used to avoid false negatives and overdeterrence. ${ }^{26}$ Second, the Commission's bipartisan nature and the use of majority rule also have provided significant constraints over most of its history. Finally, if this is the main concern, his remedy proposal instead might be that the FTC be forced to all litigate its complaints in District Court. ${ }^{27}$

My concern is that an efficiency safe harbor would neutralize virtually the entire gap-filling role of Section 5 enforcement. It often is simple for counsel or their economists to formulate "plausible" efficiency justifications to deter a complaint. Even a trivial efficiency benefit would satisfy the safe harbor standard. For example, extending Commissioner Wright's Example 7, suppose that product incompatibility raises significant barriers to entry that would allow a firm to raise prices by $\$ 50$, but not achieve a monopoly. ${ }^{28}$ Suppose that the incompatible product technology would lead to lower costs or better performance that are worth only (say) 50 cents to consumers, ceteris paribus. Under the efficiency safe harbor, that conduct would be immunized from Section 5 despite significant consumer harms. $^{29}$

this regard, a consumer welfare standard-but not a total welfare standard-ensures that harm to competitors is not sufficient to find a violation. This is because the harm to competitors is given the same weight as consumer benefits in the calculation of total welfare.

${ }^{22}$ For my own survey and conclusions, see Steven C. Salop, Exclusionary Conduct, Effect on Consumers, and the Flawed Profit-Sacrifice Standard, 73 ANTITRUST L.J. 311 (2006).

${ }^{23}$ Wright Statement at 9, supra note 2.

${ }^{24}$ For example, business certainty also is increased by a rule of per se illegality, as it would by a rule of per se legality. But, neither of these extreme standards generally provides the right balance.

${ }^{25}$ Wright Speech at 10 , supra note 2. See also Melamed, supra note 4.

${ }^{26}$ Wright Statement at 4-5, supra note 2.

${ }^{27}$ In fact, Commissioner Wright may be leaning in this direction. Wright Speech at 17,26, supra note 2.

${ }^{28}$ Wright Statement at 14, supra note 2.

${ }^{29}$ For example, Stone Container's communications regarding exchange agreements with rivals plausibly could have reduced costs, even as it facilitated price increases and reduced output. In the Matter of Stone Container (February 25, 1998), available at http://www.ftc.gov/os/1998/02/9510006.cmp.htm. 
Commissioner Ohlhausen suggests either the efficiency safe harbor or a required showing that the harm to competition is "disproportionate to its benefits." ${ }^{30}$ While a disproportionate harm standard is superior to the safe harbor for preventing over-deterrence and false positives, it raises similar false negatives and under-deterrence concerns. It places an unnecessary "thumb on the scale," particularly in light of the weak sanction and the constraints that flow generally from the Commission being a bipartisan group with majority voting and an expert economic staff.

The disproportionate harm standard also would not provide transparency or eliminate business uncertainty. Commissioners likely would differ in their determination, perhaps substantially, on how heavy a thumb to place to the scale, so it would be necessary to predict the thumb of the "median" Commissioner for the case. This diversity of types of conduct also raises the question of the appropriate weight of the thumb for each of the different types of conduct. This subjectivity can lead to uncertainty and under-deterrence. ${ }^{31}$

Her proposal also adds several other restrictions, such as determining whether there is a conflict with another federal agency, whether another agency would be a more effective enforcer, or whether a non-enforcement remedy might be sufficient. ${ }^{32}$ These additional conditions seem unnecessary and potentially counterproductive. It is not unusual for conduct to be subject to the rules of several agencies with somewhat different statutes. For example, the DOJ and FCC both review telecom mergers, the DOJ under the Clayton Act antitrust standard and the FCC under the Communications Act public interest standard. Avoiding conflict with other agencies also runs the risk of interfering with the FTC's wellregarded state action programs. Non-binding voluntary action by the respondent always can substitute for law enforcement, but would provide significantly less deterrence. ${ }^{33}$

\section{CONCLUSION}

For these reasons, antitrust enforcement and deterrence would be better served by a Section 5 UMC rule of reason standard that evaluates whether there is likely consumer harm from market power, even after taking into account the consumer benefits from cognizable efficiencies passed on consumers. This rule of reason standard is sufficient. There is no need-and there are serious risks of underdeterrence-from a Section 5 legal standard or enforcement guidelines that also include an efficiency safe harbor, a disproportionate harm standard, or other additional restrictions. However, whether the Commission can reach consensus on this or another standard remains the big open question.

${ }^{30}$ Ohlhausen Speech at 7-8, 10, supra note 2.

${ }^{31}$ For a discussion of how under-deterrence results generally from both false positives and false negatives, see Steven C. Salop, Merger Settlement and Enforcement Policy for Optimal Deterrence and Maximum Welfare, 81 FORDHAM L.R. 2647, 2668-69.

32 Ohlhausen Speech at 11-13, supra note 2.

${ }^{33}$ For criticism of non-binding settlements, see Steven C. Salop, What Consensus? Why Elections Still Matter to Antitrust, __ ANTITRUST L.J. __ (forthcoming). An earlier version is available at http://papers.ssrn.com/sol3/papers.cfm?abstract_id=2255531. 